\title{
CORRESPONDENCE.
}

ON MR. SAMUEL YOUNGER'S PLAN FOR THE ASSURANCE OF INVALID LIVES.

To the Editor of the Assurance Magazine.

SIR, - I have been for some time expecting to see a notice in the Assurance Magazine of the remarkable plan for the assurance of invalid voL. $\mathbf{x}$. 
lives, suggested by Mr. Morrice Black, of the London and Yorkshire Office, and I have read with interest the paper of my friend, Mr. Younger, in the Number just issued. It appears to me, however, that there is a fundamental error of principle which renders both of the proposed plans unsound, and which the palliative considerations set forth by Mr. Younger do not affect.

The payment for a contingency ought never to depend on the issue of the event. An ordinary assurance on a healthy life, it has often been pointed out, is a transaction in the nature of a wager-morally harmless, it is true, but still a wager upon the happening of an event unknown to either party. If the life survive the year of payment of the premium, the Company stands to win; if it die, the Company will lose: and as the latter event is antecedently less probable, the Company gives odds to the assured. But as soon as the year has expired the transaction is elosed: the assured cannot say, "The life bas survived, return me my money;" nor the Company, if the death has happened, "We will pay you baek what we have received from you, and no more." It is true the Company has entered simultaneously upon many other similar transactions, and expects to be neither a loser nor a gainer on the whole extent of them; but that is its own risk, not the risk of the assured. The proportion of the premium to the sum assured-that is, the amount of the odds given by the Companyis settled according to what are erroneously termed the "laws" of mortality, which are really only the results of past experience as extensive as we can collect. Those "laws" promise no certainty of life equivalent to the odds given, but merely enable the Company to say at what rate they can afford to run the risk.

An assurance upon an invalid life differs in no respect from an ordinary assurance, except that the rate of-odds the Company can afford to give is matter of more anxious calculation. Whatever that rate may be, when fixed upon an antecedent investigation into the case, it must not be disturbed when the contingency is at an end. If, upon an individual case, or any number of cases, the Company find the transaction result in a loss, they must abide it; if they have made profit, the profit is legitimate, having regard to the antecedently equivalent risk of loss. There cannot be an " error" or " mistake," for subsequent remedy, in the estimate put originally upon the risk.

It is a second fallacy, I conceive, to "assume that the fact of a person, whose life was considered an extra-hazardons one, living to the end of the 'expectation' period, is complete evidence that the medical opinion was wrong, and that no additional premium was necessary." Reflection will show that the "expectation of life" means nothing whatever. It is merely an arithmetical result. It does not import that any one person, or any number of persons, will live that term of years; but only that, if you add the years lifetime of a number of persons together, and divide by the number of lives observed, you obtain a given result. If some die $n$ years earlier, others will die $n$ years later. Those who live beyond have not really "exceeded their expectation;" if it were so, all would live till the last age in the tables, for the "expected" age at death increases with every year of life completed. The "expectation" is not an element in the premium to be charged, nor is it a measure of time available for any purpose whatever.

By way of illustration, take the case of a person aged 30 , as set forth in 
Mr. Younger's example, to whose age the medical adviser recommends an addition of 10 years to be made for the purpose of calculating the preminm to be charged-thus removing him from a class whose supposed "expectation" is 34 years, to one whose supposed "expectation" is 28 years. Now, even if it were admitted that the payment should abide the issne of the event, that issue would not arise at the end of 28 years, or at the end of 34 years, as suggested by Mr. Younger, but at the end of such a period as would make the average duration of the assurance for all who have been exposed to the risk, including those who have died previously to the supposed expectation, not less than 28 years.

I see that Mr. Younger admits he has "departed from theory;" but I think that the experience of all Offices which have entertained invalid assurance wonld show that such departures on the wrong side are very dangerous. It is a most hazardous class of business, and the Company requires every practical and theoretical barrier against loss that can be devised. Every plan which charges a debt upon the policy, to be wiped off at a future day if the death has not intervened, whether the debt be estimated upon the careful method of Mr. Younger, or by the more empirical modes adopted by the Offices which advertise the system, deprives the Company of the chance of profit which alone can compensate them for the concurrent chance of loss; and enables the assured in effect to say to the Company, "Heads, I win; tails, you lose." Indeed, any debt whatever upon a policy is unsound, and subversive of the principles of assurance.

It may be worth while to add, as collateral to the snbject, that what has been said does not affect the question of returning a bonus to the assured out of the resulting profit of a series of transactions, if such profit has arisen from prudent investment, gain of interest beyond that involved in the tables, economy in expenditure, or other like canses. But bonus ought never to be divided ont of profit supposed to arise from a more favourable past experience than that for which the rates of premium have provided; and those Companies who boast that their claims have been less than the expected amount, unless they retain in their hands the money so saved, are congratulating themselves upon what is really a presage of fnture disaster, as far as the policies under observation are concerned. For the deaths that have been hitherto avoided are yet to happen, inasmuch as every death must occur at some time; and the fact that, in the early years of a Company, or of a series of policies, the mortality has been less than the tables wonld have allowed for, leads to the inference that in future years (as regards those policies) the deaths will exceed the expected amount to the same extent. And this, which theory leads ns to anticipate, experience shows to be the actual result; for the advantage of medical selection ceases in a very few years, and the self-selection of the assured against the Company overbalances it-the good lives dropping their policies upon slight temptation, but the impaired lives keeping theirs in force at all risks, knowing them to be a property which, once lost, cannot be replaced. Reserve must, therefore, be made, not only for the expected mortality according to the "law," but also for the probability that the real futare mortality will exceed it.

These may be "old-school" views; but I am inclined to think that the avidity of policy-holders for bonus, and the extraordinary measures of advertising now adopted, are evil results of the competition of the last few 
years, and that it should be the part of your Magazine to maintain soundly conservative doctrines in life assurance. I crave yonr pardon for tronbling you with these remarks, not having the honour of belonging to the Institute which your Journal represents with so much ability; but I believe you do not consider that qualification essential to correspondence with you.

\title{
I am, Sir,
}

Your obedient servant,

\author{
27, Regent Street, \\ Oetober, 1862.
}

EDWARD W. BRABROOK, F.S.A.

P.S.-I add one line, to congratulate Mr. Younger and the Institute on his election as a Fellow; though we happen to differ on this occasion, a long acquaintance with him has led me to hold him and his merits in very high regard.

\author{
E. W. B.
}

\section{ON MR. SAMUEL YOUNGER'S PLAN FOR THE ASSURANCE OF INVALID LIVES.}

\section{To the Editor of the Assurance Magazine.}

Sir, - Will you allow me space for a few remarks on Mr. Yonnger's paper, in your last Number, on the assurance of diseased lives, as I think that gentleman rather needlessly complicates a comparatively simple matter.

A person desirous of making a specific annual payment or investment for the assurance of his life, bas, obviously, various alternatives to choose from. He may assure the same sum over the whole period of life--a larger sum for but a part of his life-or a sum increasing by a certain ratio, as in most ordinary "Bonus" assurances. He may stipulate that the risk of the Office shall only commence a fixed number of years hence, as in a printed table now before me; or, as in the case detailed by Mr. Yonnger, it may be an understanding that the risk of the Ofice shall be for one (smaller) sum during an earlier period of the assurance, and for a larger sum thereafter-the fixed terms being, the amount of premium to be paid, the larger sum for which the Oflice is to be responsible, and the period when the larger risk is to commence; the variable term being the amount of risk during the earlier period. Of course, such a system can be carried ont only within certain limits, and the amount of the smaller risk is obtained by the simple equation-

$$
\mathrm{S}=\frac{\mathrm{AM}_{x}-\pi \mathrm{N}_{x-1}}{\mathrm{M}_{x}-\mathrm{M}_{x+n}},
$$

where $S$ is the smaller amount required, $\pi$ the premium agreed to be paid, reduced by its proportion of offee loading or commission, A the larger assurance agreed on, and $n$ the number of years for which the risk of it is deferred.

By this we may work ont the first example given by Mr. Yonnger, where $x=35$ (the assumed age of the diseased life), $n=34, \mathrm{~A}=100$, and $\pi=1 \cdot 7554$, the net annual premium by the Carlisle 4 per cent. table for a life assurance of $£ 100$, at age of 30 . This preminm is perfectly arbitrary, 